\title{
Amyloid Beta Peptides Differentially Affect Hippocampal Theta Rhythms In Vitro
}

\author{
Armando I. Gutiérrez-Lerma, ${ }^{1,2}$ Benito Ordaz, ${ }^{1}$ and Fernando Peña-Ortega ${ }^{1}$ \\ ${ }^{1}$ Departamento de Neurobiología del Desarrollo y Neurofisiología, Instituto de Neurobiología, UNAM, \\ Boulevard Juriquilla 3001, 16230 Querétaro, Mexico \\ ${ }^{2}$ Departamento de Farmacobiología, Cinvestav-IPN, Calzada de los Tenorios 235, Col. Granjas Coapa, \\ 14330 México, DF, Mexico
}

Correspondence should be addressed to Fernando Peña-Ortega; jfpena@unam.mx

Received 24 March 2013; Accepted 3 June 2013

Academic Editor: John D. Wade

Copyright (C) 2013 Armando I. Gutiérrez-Lerma et al. This is an open access article distributed under the Creative Commons Attribution License, which permits unrestricted use, distribution, and reproduction in any medium, provided the original work is properly cited.

\begin{abstract}
Soluble amyloid beta peptide $(\mathrm{A} \beta)$ is responsible for the early cognitive dysfunction observed in Alzheimer's disease. Both cholinergically and glutamatergically induced hippocampal theta rhythms are related to learning and memory, spatial navigation, and spatial memory. However, these two types of theta rhythms are not identical; they are associated with different behaviors and can be differentially modulated by diverse experimental conditions. Therefore, in this study, we aimed to investigate whether or not application of soluble $\mathrm{A} \beta$ alters the two types of theta frequency oscillatory network activity generated in rat hippocampal slices by application of the cholinergic and glutamatergic agonists carbachol or DHPG, respectively. Due to previous evidence that oscillatory activity can be differentially affected by different $\mathrm{A} \beta$ peptides, we also compared $\mathrm{A} \beta_{25-35}$ and $\mathrm{A} \beta_{1-42}$ for their effects on theta rhythms in vitro at similar concentrations $(0.5$ to $1.0 \mu \mathrm{M})$. We found that $\mathrm{A} \beta_{25-35}$ reduces, with less potency than $\mathrm{A} \beta_{1-42}$, carbachol-induced population theta oscillatory activity. In contrast, DHPG-induced oscillatory activity was not affected by a high concentration of $\mathrm{A} \beta_{25-35}$ but was reduced by $\mathrm{A} \beta_{1-42}$. Our results support the idea that different amyloid peptides might alter specific cellular mechanisms related to the generation of specific neuronal network activities, instead of exerting a generalized inhibitory effect on neuronal network function.
\end{abstract}

\section{Introduction}

Alzheimer's disease $(\mathrm{AD})$ is a dementia of increasing prevalence [1], which is produced, at least in its early stages, by the extracellular accumulation of amyloid beta protein $(\mathrm{A} \beta)$ [2-4]. Early deterioration of hippocampal function, likely induced by soluble $\mathrm{A} \beta$, contributes to the initial memory deficits observed in $\mathrm{AD}$ patients [4-8]. Interestingly, $\mathrm{A} \beta$ encompasses several peptide species which differ in their length, solubility, biological activity, toxicity, and aggregation propensity $[3,4,9]$. $A \beta_{1-40}$ and $A \beta_{1-42}$ are the most abundant $\mathrm{A} \beta$ peptides found in senile plaques and vascular deposits of $\mathrm{AD}$ patients [10, 11]; however, these deposits also contain $\mathrm{A} \beta$ peptides with shorter sequences such as $A \beta_{25-35}[12-$ 14]. $A \beta_{25-35}$ can be produced in $\mathrm{AD}$ patients by enzymatic cleavage of $A \beta_{1-40}$ at its hydrophobic C-terminus [14, 15], and it has been proposed that $A \beta_{25-35}$ constitutes one of the biologically active fragments of $A \beta[12,16,17]$. Despite the extensive literature showing that the effects produced by $A \beta_{25-35}$ are mostly reproduced by the full-length sequence $[3,12,16,18-28]$, other reports indicate that this is not always the case. For instance, it has been shown that the reduction in long term potentiation (LTP) produced by $A \beta_{1-40}$ is not reproduced by $A \beta_{25-35}$ [29]. In contrast, whereas $A \beta_{25-35}$ induces intracellular actin aggregation and alters axonal transport, $A \beta_{1-42}$ does not [30]. The same pattern occurs with the increase in intracellular calcium observed after application of $A \beta_{25-35}$, which is not reproduced by $A \beta_{1-42}$ [31]. It has already been proposed that different forms of soluble $\mathrm{A} \beta$ alter cognitively related, synchronized electrical oscillatory activity in neural circuits $[9,18,19,32-$ 34]. Normal hippocampal function is strongly dependent on 
an oscillatory activity called theta rhythm [35-38] which, in lower mammals, includes oscillations ranging from 3 to $12 \mathrm{~Hz}$ [35-38]. Hippocampal theta rhythm participates in memory consolidation during REM sleep, in synaptic plasticity, in neural coding of place, and in spatial memory $[8,37,39-43]$. Interestingly, $\mathrm{AD}$ patients show alterations in theta rhythm activity $[5,44,45]$. Some reports indicate that cognitive dysfunction correlates with an increase of resting theta rhythm $[5,8,44,45]$, but other studies show a reduction of cognitive-induced theta rhythm [45]. Similar findings have been observed in transgenic mice that overproduce $\mathrm{A} \beta$ and exhibit $\mathrm{AD}$-like symptoms [8, 46-50]. The complex relationship between $\mathrm{AD}$ pathology and theta rhythms can be explained by the theta rhythm heterogeneity that exists both in humans and in mice $[51,52]$. Theta rhythms require the activation of either cholinergic or glutamatergic pathways, or both $[53,54]$, which are profoundly damaged in AD patients $[55,56]$ and severely compromised in transgenic AD mouse models [57-59]. Moreover, it is known that A $\beta$ can affect both cholinergic $[60,61]$ and glutamatergic transmission $[19,62]$. Thus, the application of $\mathrm{A} \beta$ in either the medial septum or in the hippocampus reduces theta rhythm both in vivo and in vitro $[19,33,34,63-65]$ and simultaneously induces cognitive deficits $[33,65]$. Moreover, carbachol-induced theta rhythm generation is impaired in slices obtained from tripletransgenic AD mice [48]. Despite all this evidence, it is still unknown if $\mathrm{A} \beta$ can alter cholinergically and/or glutamatergically induced theta rhythms to the same extent in vitro. We have addressed this question and also evaluated the potential differences in biological activity between $A \beta_{25-35}$ and $A \beta_{1-42}$ on both cholinergically and glutamatergically induced theta rhythms, as was done earlier for beta rhythms [9]. We tested these peptides at concentrations of $1 \mu \mathrm{M}$ or less because most studies report $\mathrm{A} \beta$ concentrations in the low $\mathrm{nM}$ range both in $\mathrm{AD}$ patients [66-70] and in $\mathrm{AD}$ transgenic mice [7174]. However, some reports show that $\mathrm{A} \beta$ in $\mathrm{AD}$ patients can reach high $\mathrm{nM}$ [75-77] or even $\mu \mathrm{M}$ concentrations $[66,78,79]$ (for a review see [80]). Our results show that $A \beta_{25-35}$ reduces, with less potency than $A \beta_{1-42}$, carbacholinduced field theta oscillatory activity. In contrast, DHPGinduced oscillatory activity was not affected by $A \beta_{25-35}$ but was reduced by $A \beta_{1-42}$.

\section{Material and Methods}

2.1. Animals. All experiments were performed using 7- to 10 -week-old male Wistar rats. Animals used in this study were housed at $22^{\circ} \mathrm{C}$ and maintained on a 12-h:12-h light/dark cycle with free access to food and water. All the experimental protocols were approved by the Local Committees of Ethics on Animal Experimentation (CICUAL-Cinvestav and INBUNAM). Experiments were performed according to the Mexican Official Norm for the Use and Care of Laboratory Animals (NOM-062-ZOO-1999).

2.2. Hippocampal Slice Preparation. Hippocampal slices were obtained as follows: the animals were anesthetized intraperitoneally with sodium pentobarbital $(63 \mathrm{mg} / \mathrm{Kg})$ and perfused transcardially with cold modified artificial cerebrospinal fluid (maCSF) of the following composition (in $\mathrm{mM}$ ): 238 sucrose,

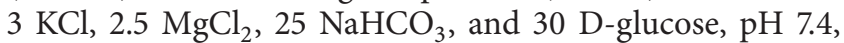
bubbled with carbogen $\left(95 \% \mathrm{O}_{2}\right.$ and $\left.5 \% \mathrm{CO}_{2}\right)$. After a maximum of $1 \mathrm{~min}$ of transcardial perfusion, the animals were decapitated, and the brains were removed and dissected in ice-cold artificial cerebrospinal fluid (aCSF) containing (in $\mathrm{mM}) 119 \mathrm{NaCl}, 3 \mathrm{KCl}, 1.5 \mathrm{CaCl}_{2}, 1 \mathrm{MgCl}_{2}, 25 \mathrm{NaHCO}_{3}$, and 30 D-glucose, $\mathrm{pH}$ 7.4, continuously bubbled with carbogen. One cerebral hemisphere was glued to an agar block with a $30^{\circ}$ inclination and mounted on a vibratome (The Vibratome Company, St. Louis, MO, USA). Horizontal slices $(400 \mu \mathrm{m}$ thick) containing the hippocampal formation were cut and left to recover at room temperature for at least $90 \mathrm{~min}$ in aCSF continuously bubbled with carbogen.

2.3. Electrophysiological Recordings. The slices were transferred to a submerged recording chamber continuously perfused at $20 \mathrm{~mL} / \mathrm{min}$ with oxygenated aCSF. The temperature was kept constant at $29 \pm 2^{\circ} \mathrm{C}$. Extracellular field recordings were obtained with suction electrodes filled with aCSF and positioned over hippocampal area CA1, stratum pyramidale $[62,81]$. The signal was amplified and filtered (highpass, $0.5 \mathrm{~Hz}$; lowpass, $1.5 \mathrm{KHz}$ ) with a wide-band AC amplifier (Grass Instruments, Quincy, MA, USA). The experimental protocol consisted of recording the spontaneous basal activity for $10 \mathrm{~min}$ before adding either the general cholinergic agonist carbachol (Cch) $[20 \mu \mathrm{M}]$ or the metabotropic glutamate group I agonist (S)-3,5-dihydroxyphenylglycine (DHPG) $[10 \mu \mathrm{M}]$ to the perfusion system in order to generate stable and persistent oscillatory activity [53]. Then, we added freshly dissolved $A \beta_{25-35}$ to the perfusion system at two different concentrations: $0.5 \mu \mathrm{M}$ and $1 \mu \mathrm{M}$ [19]. In a different set of experiments, the freshly dissolved full peptide $A \beta_{1-42}$ $[0.5 \mu \mathrm{M}]$ was also tested [62]. We used the freshly dissolved inverse sequences $A \beta_{35-25}[1 \mu \mathrm{M}]$ and $A \beta_{42-1}[0.5 \mu \mathrm{M}]$ as negative controls. In some experiments, atropine $[1 \mu \mathrm{M}]$, a broad-spectrum muscarinic acetylcholine antagonist, was added to the perfusion system to block carbachol-induced oscillations. The metabotropic glutamate receptor group 5 antagonist 2-methyl-6-(phenylethynyl) pyridine (MPEP) [25 $\mu \mathrm{M}]$ was added to block the DHPG-induced oscillations. All drugs were dissolved in distilled water and were obtained from Sigma (Sigma-RBI, St. Louis, MO). The stock solutions were prepared at concentrations of at least 1000X. In most cases $1 \mu \mathrm{L}$ of distilled water, containing the drug, was applied to $1 \mathrm{~mL}$ of aCSF which, in our hands, does not affect its osmolarity.

2.4. Data Analysis. The recordings were stored on a personal computer with an acquisition system from National Instruments (Austin, TX, USA) by using custom-made software designed in the LabView environment. The recordings obtained were analyzed off-line using the program Clampfit (Molecular Devices). The full experiments were analyzed, and for quantification purposes, segments of $100 \mathrm{sec}$ were analyzed every $10 \mathrm{~min}$, using a Fast Fourier Transform Algorithm with a Hamming window. The power spectra 
of all segments were normalized to the basal spontaneous activity of each individual experiment or normalized to the control cholinergic or glutamatergic oscillatory activity. We also performed an Autocorrelation Function Estimate to test for the self cross-correlation (rhythmicity) of the signal on short ( $1 \mathrm{sec}$ window) traces. All data are expressed as mean \pm standard error of the mean (SEM). In most cases the data distribution was markedly skewed, and hence we used a Mann-Whitney Rank Sum Test with statistical significance denoted by $P<0.05$, or a Kruskal-Wallis One-Way Analysis of Variance on Ranks followed by either Dunn's Method for Multiple Comparisons versus Control Group or for All Pairwise Multiple Comparison. Differences with statistical significance are denoted by $P<0.001$.

\section{Results}

\subsection{A $\beta$ Peptides Inhibit Carbachol-Induced Hippocampal} Theta Oscillatory Activity. In order to study the effect of $\mathrm{A} \beta$ on cholinergically induced theta oscillatory activity, we first generated such activity by applying carbachol $[20 \mu \mathrm{M}]$ to the perfusion system [82]. In these conditions, most of the slices (10 out of 13) generated field oscillatory activity with frequency components that fall into the theta range (Figure 1(a), middle trace) and have a peak frequency of $9.8 \pm$ $0.39 \mathrm{~Hz}$ (Figure 1(a), middle power spectrum). The insets in the power spectra show the corresponding autocorrelation estimates of the hippocampal population activity, indicating that in the presence of carbachol $[20 \mu \mathrm{M}]$ rhythmic population activity emerges. The rhythmicity exhibits a high degree of self-correlation (Figure 1(a)). Quantification of power in the classical theta range $(4$ to $12 \mathrm{~Hz})[48,53]$ shows that application of carbachol $[20 \mu \mathrm{M}]$ increases the power of hippocampal population activity to $204.06 \pm 13.79 \%$ of control basal activity (Figure 1(a), right graph). The activity described maintains stability for at least $100 \mathrm{~min}(n=10)$. As expected, addition of atropine $[1 \mu \mathrm{M}]$ completely abolished the oscillatory activity generated by carbachol and even reduced the power of the hippocampal activity below control levels, to $58.18 \pm 3.64 \%$ of control basal activity (Figure 1(a)).

To test whether or not the amyloid peptides were capable of disrupting population theta oscillatory activity, we applied them to the bath after the application of carbachol. Addition of $A \beta_{25-35}[0.5 \mu \mathrm{M}]$ to the perfusion system did not significantly change carbachol-induced theta oscillations (Figure 1(b)). However, it is important to notice that $A \beta_{25-35}$ $[0.5 \mu \mathrm{M}]$ shows a slight tendency to increase such activity (to $140.01 \pm 19.86 \%$ of the cholinergic control (Figure 1(b); $n=$ $8)$ ). In the presence of $A \beta_{25-35}[0.5 \mu \mathrm{M}]$ the peak oscillatory frequency remained unaffected $(10.17 \pm 0.78 \mathrm{~Hz})$. Increasing $A \beta_{25-35}$ concentration, in an independent group of slices, to $1 \mu \mathrm{M}$ reduced cholinergically induced theta oscillations to $47.93 \pm 8.77 \%$ of the cholinergic control (Figure $1(\mathrm{~b})$; $n=9$ ). Likewise, the peak oscillatory frequency diminished significantly to $5.57 \pm 1.26 \mathrm{~Hz}$. Similarly, application of the full peptide $A \beta_{1-42}[0.5 \mu \mathrm{M}]$ reduced the cholinergically induced theta oscillations to $42.60 \pm 13.28 \%$ of the cholinergic control (Figure $1(\mathrm{c}) ; n=4$ ); this inhibition in power was accompanied by a significant reduction in the peak oscillatory frequency to $6.45 \pm 1.43 \mathrm{~Hz}$.

As an internal control, we washed out the $A \beta_{25-35}[1 \mu \mathrm{M}]$ with aCSF containing carbachol $[20 \mu \mathrm{M}]$ and found that the population theta oscillatory activity returned to nearly the same power level as before application of $A \beta_{25-35}[1 \mu \mathrm{M}]$ $(89.40 \pm 5.95 \%$ of the cholinergic control; Figure 2(a), graph and lower trace; $n=4)$. The peak oscillatory frequency was also restored upon washout $(8.56 \pm 1.06 \mathrm{~Hz}$; Figure 2 (a), lower power spectrum; $n=4$ ), and the rhythmicity of the theta oscillatory activity was identical to that observed before the application of $A \beta_{25-35}[1 \mu \mathrm{M}]$ (Figure 2(a), upper inset). To test for the specificity of the effect produced by $A \beta_{25-35}$, we used its inverse sequence $A \beta_{35-25}[1 \mu \mathrm{M}]$ and found no effect on the carbachol-induced theta oscillations (Figure 2(b)). The power of the activity remained unaltered in the presence of $A \beta_{35-25}$ (97.00 $\pm 9.16 \%$ of the cholinergic control, $n=$ 10; Figure 2(b), graph and middle trace), and the peak theta frequency remained unaltered as well $(8.49 \pm 0.49 \mathrm{~Hz}$, $n=10$, Figure $2(\mathrm{~b})$, middle power spectrum). Of course, subsequent application of $A \beta_{25-35}[1 \mu \mathrm{M}]$ in the continued presence of $A \beta_{35-25}(1 \mu \mathrm{M})$ reduced the carbachol-induced theta oscillations to $33.71 \pm 10.19 \%$ of the cholinergic control (Figure 2(b), lower trace and power spectrum). We also tested the effect of the inverse sequence $A \beta_{42-1}[0.5 \mu \mathrm{M}]$ and found that this peptide sequence does not significantly alter carbachol-induced activity $(81.57 \pm 26.67 \%$ of the cholinergic control, $n=5$ ).

\subsection{A $\beta$ Peptides Differentially Affect DHPG-Induced} Delta/Theta Oscillatory Activity. As mentioned earlier, theta rhythm can also be induced by glutamatergic activation, mainly through metabotropic group I receptors $[53,83]$. In order to study the effect of $\mathrm{A} \beta$ on glutamatergically induced theta oscillatory activity, we first generated such activity by applying DHPG $[10 \mu \mathrm{M}]$ to the perfusion system. In these conditions, most of the slices ( 8 out of 10 ) generated oscillatory activity with frequency components slower than those present in cholinergically induced oscillatory activity, ranging from 2 to $10 \mathrm{~Hz}$ in the mixed delta/theta rhythm range (Figure $3(\mathrm{a}) ; n=8$ ) with a mean peak frequency of $5.71 \pm 0.92 \mathrm{~Hz}$ (Figure $3(\mathrm{a})$, middle power spectrum). The insets in the power spectra show the corresponding autocorrelations of the hippocampal population activity indicating that, in the presence of DHPG $[10 \mu \mathrm{M}]$, rhythmic population activity emerges and is characterized by a high degree of self-correlation (Figure 3(a), inset). Quantification of power in the delta/theta range (2 to $10 \mathrm{~Hz}$ ) shows that application of DHPG $[10 \mu \mathrm{M}]$ increases the power of hippocampal population activity to $207.47 \pm 13.66 \%$ of the control basal activity (Figure 3(a), right graph). This activity was stable for at least $100 \mathrm{~min}(n=8)$. As expected, addition of MPEP $[25 \mu \mathrm{M}]$ completely abolished the oscillatory activity generated by DHPG and reduced the power of the hippocampal activity to $110 \pm 8.24 \%$ of control basal activity (Figure 3(a), lower trace and power spectrum). To test whether or not the amyloid peptides were capable of disrupting the glutamatergic population theta oscillatory activity, we added them after the application of DHPG. 


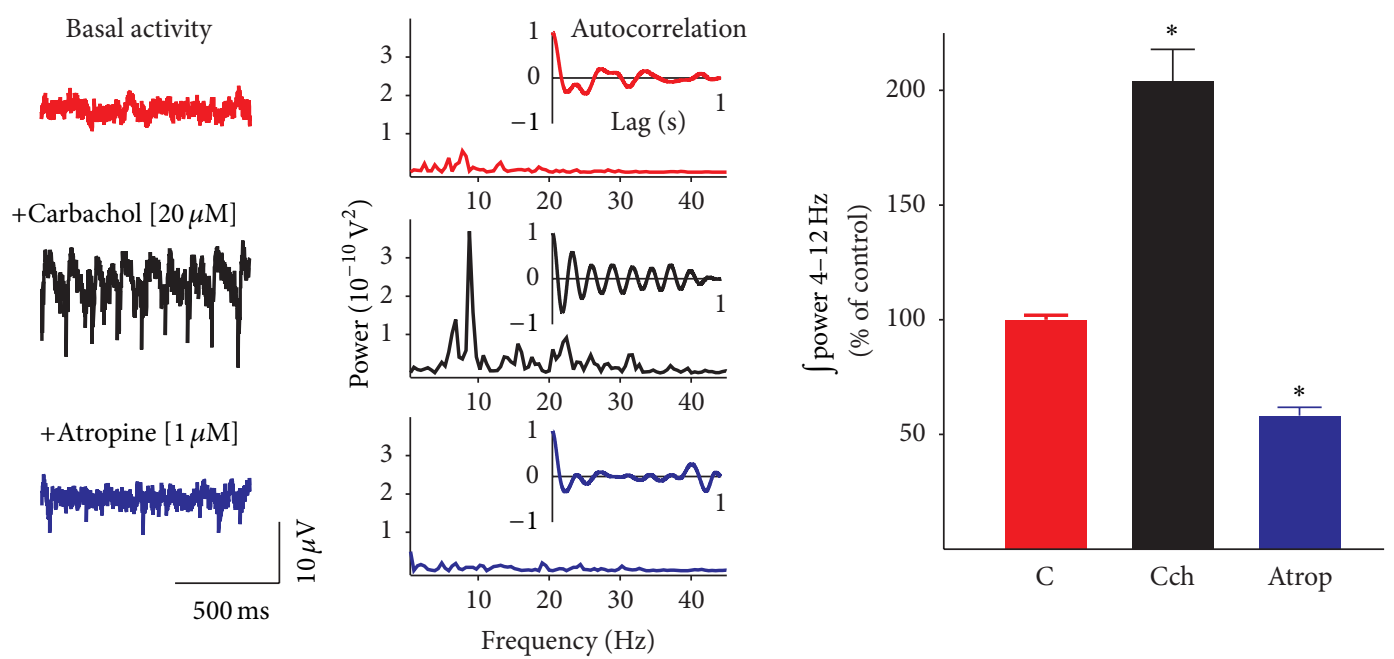

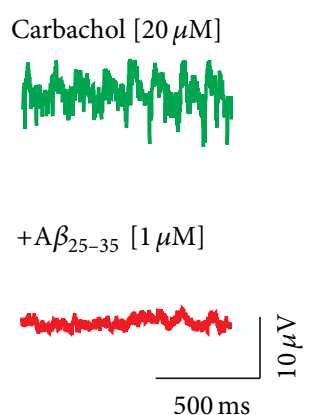
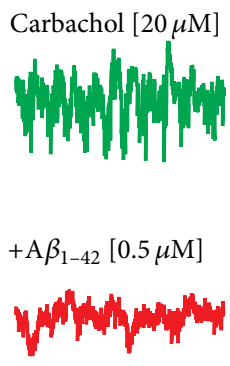

$500 \mathrm{~ms}$

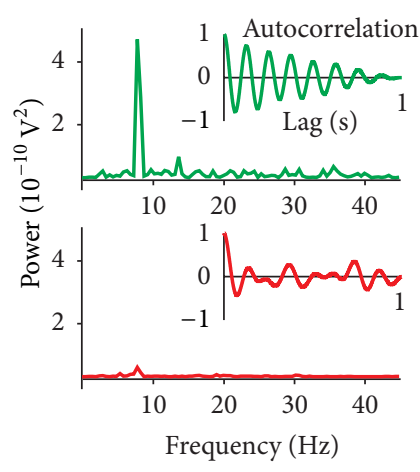

(b)

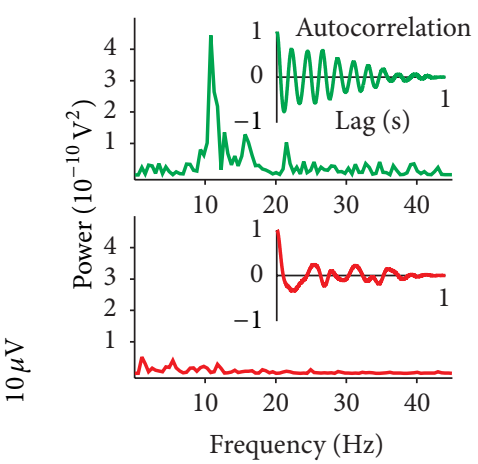

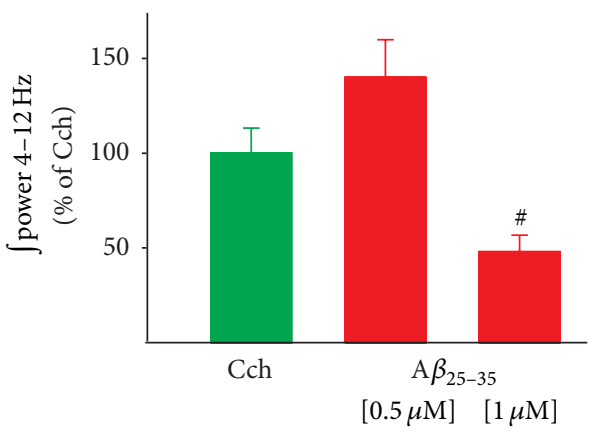

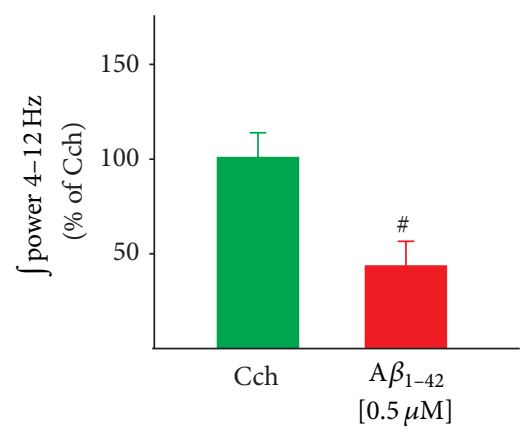

(c)

FIGURE 1: Amyloid beta peptides inhibit carbachol-induced hippocampal theta oscillatory activity. (a) Representative recordings (left) and the corresponding power spectra (right) of hippocampal population activity recorded in control conditions (upper trace and power spectrum) after bath application of carbachol (Cch $20 \mu \mathrm{M}$; middle trace and power spectrum) and after the application of atropine $1 \mu \mathrm{M}$ (lower trace and power spectrum). The graph on the right shows the quantification of the integrated spectral power from 4 to $12 \mathrm{~Hz}$. Note that the addition of Cch induces atropine-sensitive rhythmic oscillations that increase the power of the hippocampal population activity. (b) Representative recordings (left) and the corresponding power spectra (right) of hippocampal population activity recorded in the presence of carbachol $20 \mu \mathrm{M}$ (upper trace and power spectrum) and after bath application of $A \beta_{25-35} 1 \mu \mathrm{M}$ (lower trace and power spectrum). The graph on the right shows the quantification of the integrated spectral power from 4 to $12 \mathrm{~Hz}$ before and after bath application of $A \beta_{25-35}[0.5 \mu \mathrm{M}]$ and $[1 \mu \mathrm{M}]$. Note that a high concentration of $A \beta_{25-35}$ inhibits Cch-induced rhythmic theta oscillations and that a lower concentration does not affect this activity. (c) Representative recordings (left) and their corresponding power spectra (right) of hippocampal population activity recorded in the presence of carbachol $20 \mu \mathrm{M}$ (upper trace and power spectrum) and after bath application of $A \beta_{1-42} 0.5 \mu \mathrm{M}$ (lower trace and power spectrum). The graph on the right shows the quantification of the integrated spectral power from 4 to $12 \mathrm{~Hz}$ before and after bath application of $A \beta_{1-42}$. Note that $A \beta_{1-42}$ inhibits Cch-induced rhythmic theta oscillations. The inset shown on each power spectrum is an autocorrelogram obtained from the corresponding trace. ${ }^{*}$ indicates a significant difference with respect to control $(P<0.001)$, and ${ }^{\#}$ indicates a significant difference with respect to the carbachol-induced oscillatory activity. 

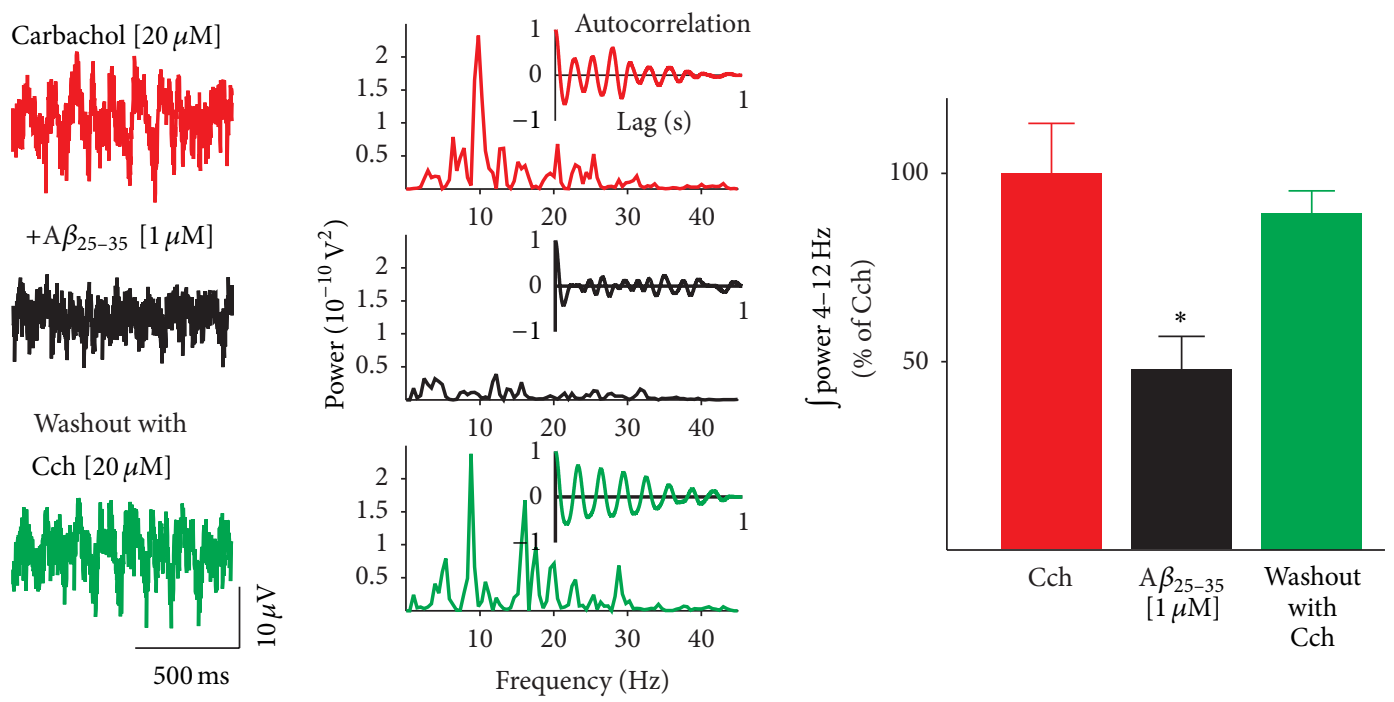

(a)
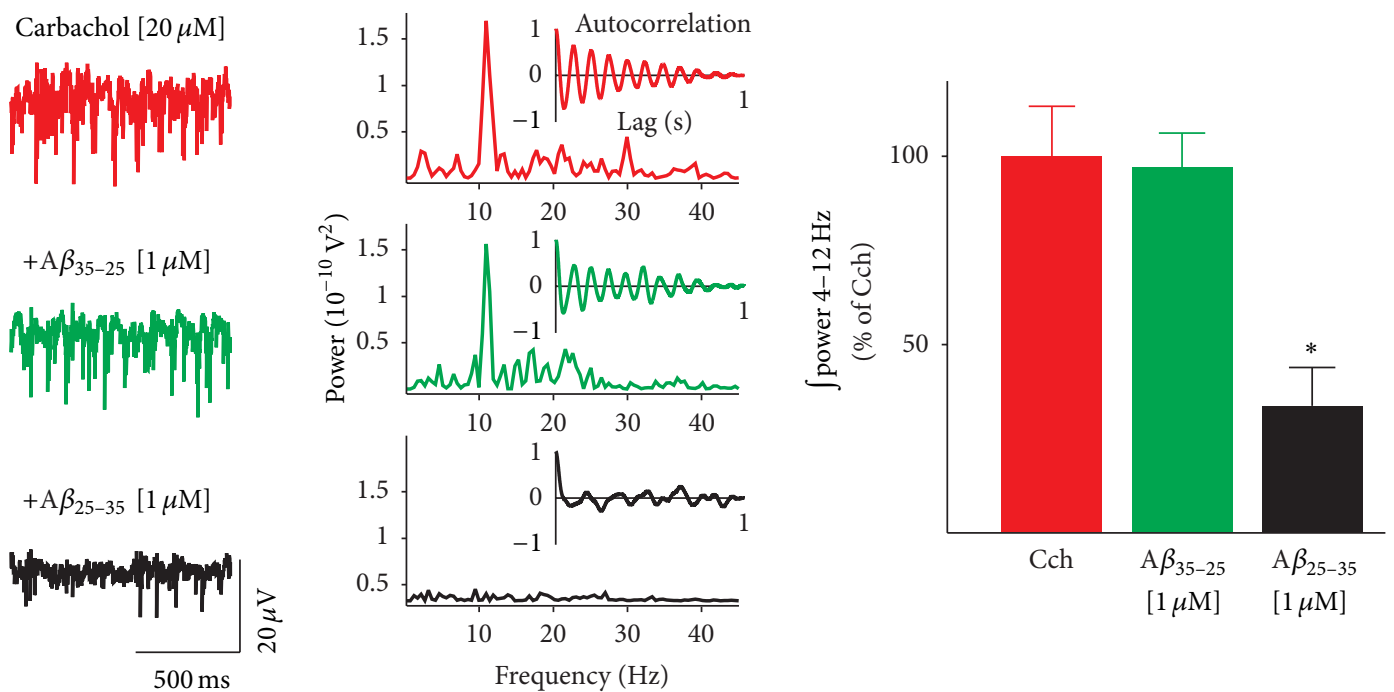

(b)

FIgURE 2: Amyloid beta inhibition of carbachol-induced hippocampal theta oscillatory activity is reversible and specific. (a) Representative recordings (left) and the corresponding power spectra (right) of hippocampal population activity recorded in the presence of carbachol $20 \mu \mathrm{M}$ (upper trace and power spectrum) after bath application of $A \beta_{25-35} 1 \mu \mathrm{M}$ (middle trace and power spectrum) and after washout of $\mathrm{A} \beta$ (in the presence of carbachol $20 \mu \mathrm{M}$; lower trace and power spectrum). The graph on the right shows the quantification of the integrated spectral power from 4 to $12 \mathrm{~Hz}$. Note that the $A \beta_{25-35}$-induced inhibition of theta activity is reversible upon washout. (b) Representative recordings (left) and the corresponding power spectra (right) of hippocampal population activity recorded in the presence of carbachol $20 \mu \mathrm{M}$ (upper trace and power spectrum) after bath application of the inverse sequence of $A \beta_{25-35}, A \beta_{35-25}[1 \mu \mathrm{M}]$ (middle trace and power spectrum) and after bath application of $A \beta_{25-35} 1 \mu \mathrm{M}$ (in the presence of carbachol; lower trace and power spectrum). The inset shown on each power spectrum is an autocorrelogram obtained from the corresponding trace. The graph on the right shows the quantification of the integrated spectral power from 4 to $12 \mathrm{~Hz}$. Note that the inverse sequence $A \beta_{35-25}$ has no effect on the theta rhythm. ${ }^{*}$ indicates a significant difference with respect to the carbachol-induced oscillatory activity $(P<0.001)$.

Addition of $A \beta_{25-35}[1 \mu \mathrm{M}]$ to the perfusion system did not significantly change DHPG-induced delta/theta oscillations $(120.52 \pm 12.92 \%$ of the glutamatergic control; Figure $3(\mathrm{~b})$, graph, lower trace and power spectrum). In the presence of $A \beta_{25-35}[1 \mu \mathrm{M}]$, the peak oscillatory frequency remained unaffected $(7.57 \pm 0.64 \mathrm{~Hz} ; n=10)$. In contrast, application of full length $A \beta_{1-42}[0.5 \mu \mathrm{M}]$ reduced DHPG-induced theta oscillations to $33.27 \pm 8.92 \%$ of the glutamatergic control (Figure 3(c), graph, lower trace and power spectrum; $n=4$ ). However, such inhibition in power was not accompanied by a significant reduction of the peak oscillatory frequency, which was $5.77 \pm 1.12 \mathrm{~Hz}$. 


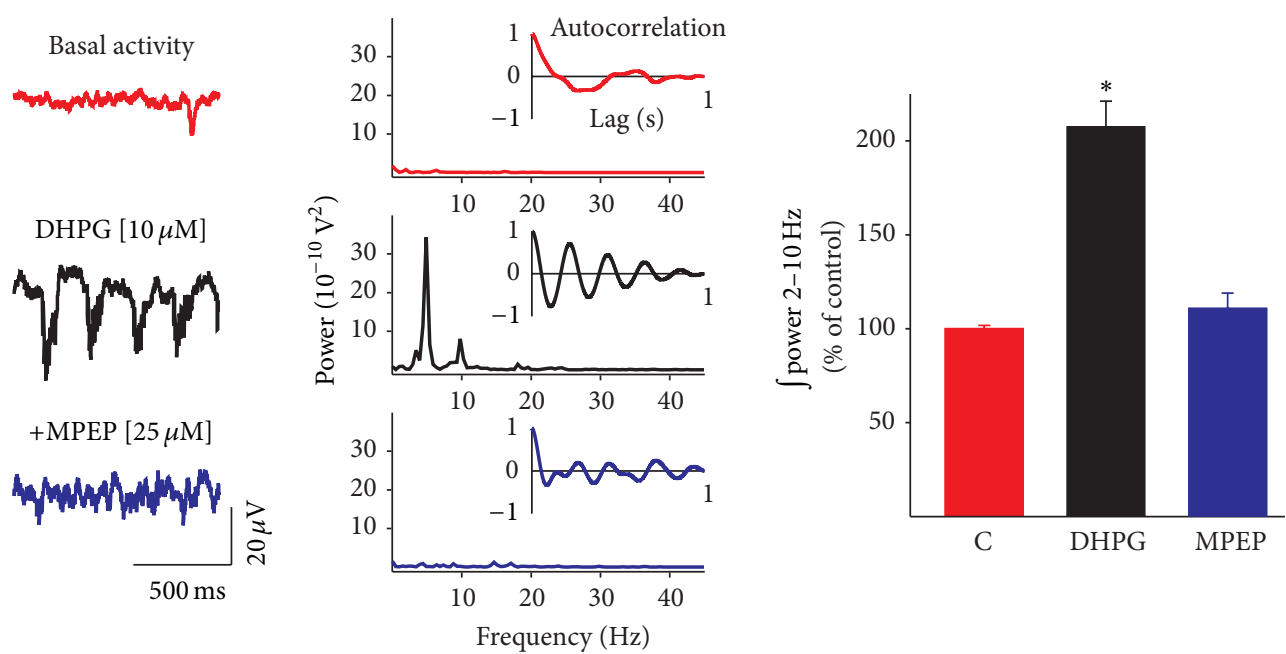

(a)
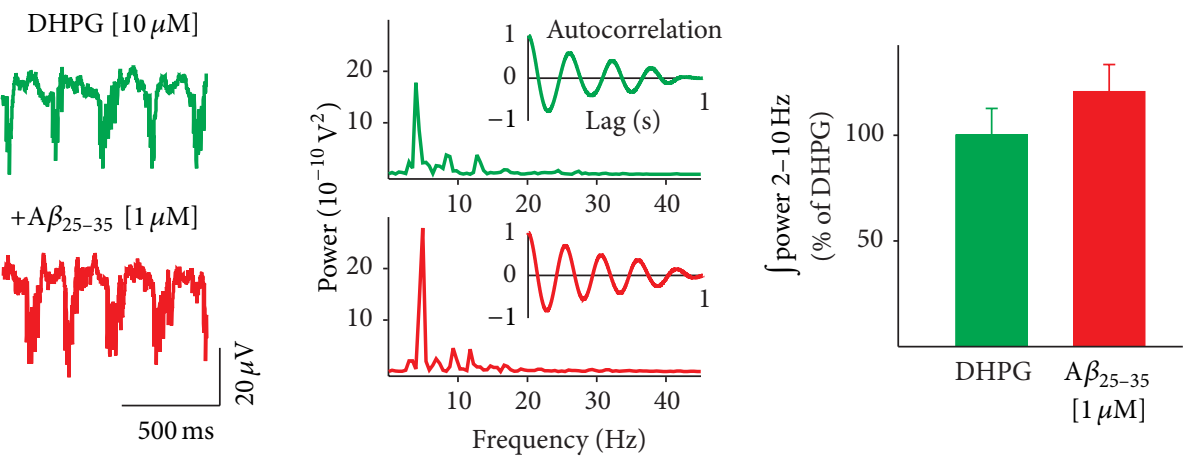

(b)
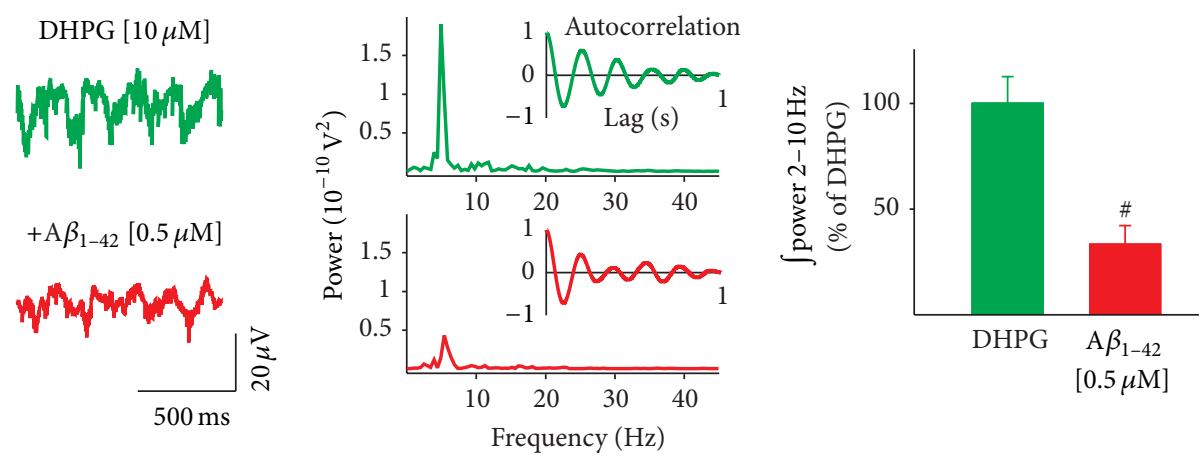

(c)

FIgURE 3: Amyloid beta peptides differentially inhibit DHPG-induced hippocampal theta oscillatory activity. (a) Representative recordings (left) and their corresponding power spectra (right) of hippocampal population activity recorded in control conditions (upper trace and power spectrum), after bath application of DHPG $10 \mu \mathrm{M}$ (middle trace and power spectrum) and after the application of MPEP $25 \mu \mathrm{M}$ (lower trace and power spectrum). The graph on the right shows the quantification of the integrated spectral power from 2 to $10 \mathrm{~Hz}$. Note that DHPG induces MPEP-sensitive rhythmic oscillations that increase the power of the hippocampal population activity. (b) Representative recordings (left) and the corresponding power spectra (right) of hippocampal population activity recorded in the presence of DHPG $10 \mu \mathrm{M}$ (upper trace and power spectrum) and after bath application of $A \beta_{25-35} 1 \mu \mathrm{M}$ (lower trace and power spectrum). The graph on the right shows the quantification of the integrated spectral power from 2 to $10 \mathrm{~Hz}$. Note that $A \beta_{25-35}$ does not affect DHPG-induced oscillatory activity. (c) Representative recordings (left) and the corresponding power spectra (right) of hippocampal population activity recorded in the presence of DHPG $10 \mu \mathrm{M}$ (upper trace and power spectrum) and after bath application of $A \beta_{1-42} 0.5 \mu \mathrm{M}$ (lower trace and power spectrum). The inset shown on each power spectrum is an autocorrelogram obtained from the corresponding trace. The graph on the right shows the quantification of the integrated spectral power from 2 to $10 \mathrm{~Hz}$. Note that $A \beta_{1-42}$ inhibits DHPG-induced rhythmic theta oscillations. ${ }^{*}$ indicates a significant difference with respect to control $(P<0.001)$, and ${ }^{\#}$ indicates a significant difference with respect to the DHPG-induced oscillatory activity. 


\section{Discussion}

The study of theta rhythm generation as well as its alterations in several neurological pathologies has received a great deal of attention $[8,84]$. Such research has revealed that instead of a single theta rhythm, there actually exist a variety of rhythms that are involved in different behaviors and rely on different cellular mechanisms $[52,85]$. In general, it has been proposed that theta rhythms are evoked through either cholinergic or glutamatergic means $[8,53,84]$. Our finding that $\mathrm{A} \beta$ affects both types of theta rhythms is of particular importance, given that both cholinergic and glutamatergic neurotransmission are necessary to generate cognitive-related theta network oscillatory activity (as reviewed by [84]), and therefore any pathological disruption in the normal function of either neurotransmitter system will generate cognitive dysfunction and, eventually, dementia. Previous research has shown that soluble $\mathrm{A} \beta$ affects the power, frequency, and structure of synchronized oscillatory activity, mainly theta and gamma rhythms, which are strongly related to cognition $[9,18,19$, $32-34,64,65]$ and that such activity is disrupted in AD patients $[5,44,86,87]$ and in $\mathrm{AD}$ transgenic mice [46-50]. As we have previously shown that theta generation in vivo is affected by both $A \beta_{25-35}$ [19] and $A \beta_{1-42}$ [34], we took this knowledge a step further and tested whether or not freshly dissolved $A \beta$ affected the power and frequency of either cholinergically or glutamatergically induced hippocampal population theta oscillatory activity in slices in vitro. We found that different sequences of $\mathrm{A} \beta$ induce, with some differences in potency, a statistically significant reduction in power of cholinergic population theta oscillatory activity. In contrast, glutamatergically induced oscillatory activity was not sensitive to the application of $A \beta_{25-35}$, whereas it was strongly inhibited by $A \beta_{1-42}$. The mechanisms involved in the $\mathrm{A} \beta$-induced reduction of both cholinergically and glutamatergically generated population theta oscillatory activity are not clear, and there are several cellular and molecular targets through which $\mathrm{A} \beta$ can pathologically interact to produce synaptic and cellular dysfunction (as reviewed in $[3,88])$. However, very recent evidence indicates that $\mathrm{A} \beta$ affects the oscillatory activity of the hippocampus mainly in two ways: the first one is a generalized reduction of both glutamatergic and GABAergic transmission of presynaptic origin $[19,62,89,90]$, and the second involves alterations in specific subpopulations of GABAergic interneurons [33, 8991]. Additionally, carbachol induces rhythmic oscillations of membrane potential in hippocampal neurons that allow them to engage in the theta oscillatory rhythm [92]. It has been shown that such subthreshold oscillations are abolished by $\mathrm{A} \beta$ when they are induced by carbachol induction [18] or through application of depolarizing DC current [19]. Regarding the biochemical mechanisms involved in this effect, both muscarinic acetylcholine M1/M3 receptors and group I metabotropic glutamate receptors modulate several cellular mechanisms by activating phospholipase $\mathrm{C}$ and protein kinase $C(P K C)[83,93]$. It has been shown that the activation of PKC mediated by carbachol is disrupted by A $\beta$ [94], whereas the activation of PKC induced by ACPD, a general metabotropic glutamate agonist, is completely unaffected by
$\mathrm{A} \beta$ [94]. Another important factor to take into account is that, as it has already been suggested, carbachol and DHPG most probably generate oscillatory activity through the activation of different subsets of hippocampal interneurons [53], and, therefore, $\mathrm{A} \beta$ may pathologically alter the proper function of some, but not of other kinds of interneurons, which may also explain why DHPG-induced oscillatory activity is resistant to $A \beta_{25-35}$. Another possible explanation for the higher sensitivity of carbachol-induced theta rhythm to bath application of $\mathrm{A} \beta$ compared to DHPG-induced theta rhythms has emerged from the recent finding that $\mathrm{A} \beta$ directly disrupts the M1 muscarinic receptor/G-protein interaction [95]. In contrast, to our knowledge, such direct disruption has not been demonstrated for metabotropic glutamatergic receptors. To finish with this point, it is important to mention that, just like the theta oscillatory activity generated with DHPG, potassium-induced hippocampal beta rhythm was reduced by $A \beta_{1-42}$ but was resistant to $A \beta_{25-35}$ [9]. In our previous studies, we had tested the changes in hippocampal population activity induced by $A \beta_{25-35}$ at concentrations ranging from $300 \mathrm{nM}$ to $3 \mu \mathrm{M}[9,19]$, whereas $A \beta_{1-42}$ has been tested in the range from $10 \mathrm{nM}$ to $0.5 \mu \mathrm{M}[19$, 62]. Based on our previous observations, and those from others, we decided to use a common concentration of both peptides of $0.5 \mu \mathrm{M}$, which had already been shown to produce similar effects on hippocampal population activity [19].

In another series of experiments, we washed out the peptide $A \beta_{25-35}[1 \mu \mathrm{M}]$ from the system with aCSF containing carbachol, and both peak frequency and power of the theta field oscillatory activity were completely restored; therefore, the reduction of field oscillatory activity induced by $\mathrm{A} \beta$ is completely reversible. We have shown previously that inhibition of hippocampal population activity induced by $A \beta_{25-35}$ and $A \beta_{1-42}$ is equally reversible $[19,62]$. The reversibility of the effect of $A \beta_{25-35}$ on theta rhythm observed here corroborates these previous findings and gives us confidence that the effects induced by $A \beta_{1-42}$ are reversible as well [62]. The reversibility of the effects induced by $\mathrm{A} \beta$ suggests that soluble $\mathrm{A} \beta$ does not permanently damage the neural circuitry needed to generate theta oscillatory activity in vitro, and secondly, it strongly supports the idea that soluble $\mathrm{A} \beta$ produces synaptic impairment rather than irreversible synaptic loss in vitro. Finally, we also tested the $\mathrm{A} \beta$ inverse sequences as a control for the specificity of the biological activity of the $\mathrm{A} \beta$ peptides used; as expected, the inverse sequences had no effect at all on either the peak frequency or the power of the cholinergically induced population theta oscillatory activity. As additional proof that $\mathrm{A} \beta$ has biological effects that are sequence and conformation specific, in the presence of the inverse sequence $\mathrm{A} \beta_{35-25}$ we added into the perfusion system the regular sequence $A \beta_{25-35}[1 \mu \mathrm{M}]$ which, unsurprisingly, significantly reduced the power of the cholinergic theta oscillatory activity to approximately onethird of control cholinergic values. Finally, in relation to the differences in biological activity between $A \beta_{25-35}$ and $A \beta_{1-42}$, the latter always produced a reduction of theta oscillatory activity, and, furthermore, it was more effective at a lower concentration than $A \beta_{25-35}$, which is consistent with the idea 
that the most toxic $\mathrm{A} \beta$ species is soluble $A \beta_{1-42}[96,97]$, especially in its oligomerized form [98, 99]. In this study, both peptides were used in their soluble forms, which have been shown to be mainly composed of monomers and a few oligomers [100], although the precise concentrations of each aggregation species are hard to determine. Considering that the inhibition of beta rhythm hippocampal population oscillations produced by $A \beta_{25-35}$ did not exhibit a clear concentration-dependent relationship in the low $\mu \mathrm{M}$ range [9], we decided not to study higher concentrations. Given that $A \beta_{1-42}$ was the most effective peptide used in terms of disrupting theta rhythm power, it would be of interest to test the effect of chemically oligomerized $A \beta_{1-42}$ on population theta oscillatory activity induced both cholinergically and glutamatergically, since the oligomers should be even more potent at reducing the power of the theta rhythm at low concentrations.

\section{Conclusions}

In conclusion, $A \beta$ peptides, but more potently $A \beta_{1-42}$, can differentially reduce population theta oscillatory activity induced through either cholinergic or glutamatergic means, which suggests that instead of having a widespread effect, $\mathrm{A} \beta$ disrupts some particular mechanism of generation and maintenance of this activity. Importantly, this effect is sequence specific and completely reversible, suggesting that $A \beta$ produces synaptic and cognitive impairments that could be potentially delayed or reversed.

\section{Conflict of Interests}

The authors declare that they have no conflict of interests.

\section{Authors' Contribution}

F. P. Ortega designed the research. A. I. Gutiérrez-Lerma and B. Ordaz carried out the recordings and analyzed the data. A. I. Gutiérrez-Lerma and F. P. Ortega wrote the paper. All the authors read and approved the final paper.

\section{Acknowledgments}

This work was funded by Consejo Nacional de Ciencia y Tecnología (CONACyT) Grant no. 151261 and 181323 (to F. Peña-Ortega) and a scholarship 195367 (to A. I. GutiérrezLerma), by Dirección General de Asuntos del Personal Académico-UNAM Grant no. IACODI1201511 and IB200212RR280212 (to F. Peña-Ortega), and by Alzheimer's Association Grant NIRG-11-205443. This study was performed in partial fulfillment of the requirements for the Ph.D. degree in Biomedical Sciences of the Programa de Doctorado en Ciencias Biomédicas (INB, Universidad Nacional Autónoma de México) for A. I. Gutiérrez-Lerma. The authors would like to thank Dr. Dorothy Pless for editorial comments.

\section{References}

[1] L. E. Hebert, P. A. Scherr, J. L. Bienias, D. A. Bennett, and D. A. Evans, "Alzheimer disease in the US population: prevalence estimates using the 2000 census," Archives of Neurology, vol. 60, no. 8, pp. 1119-1122, 2003.

[2] H. Braak and E. Braak, "Frequency of stages of Alzheimerrelated lesions in different age categories," Neurobiology of Aging, vol. 18, no. 4, pp. 351-357, 1997.

[3] F. Peña, A. I. Gutiérrez-Lerma, R. Quiroz-Baez, and C. Arias, "The role of $\beta$-amyloid protein in synaptic function: implications for Alzheimer's disease therapy," Current Neuropharmacology, vol. 4, no. 2, pp. 149-163, 2006.

[4] D. J. Selkoe, "Alzheimer's disease is a synaptic failure," Science, vol. 298, no. 5594, pp. 789-791, 2002.

[5] C. Babiloni, M. Pievani, F. Vecchio et al., "White-matter lesions along the cholinergic tracts are related to cortical sources of eeg rhythms in amnesic mild cognitive impairment," Human Brain Mapping, vol. 30, no. 5, pp. 1431-1443, 2009.

[6] W. L. Klein, G. A. Krafft, and C. E. Finch, "Targeting small A $\beta$ oligomers: the solution to an Alzheimer's disease conundrum?" Trends in Neurosciences, vol. 24, no. 4, pp. 219-224, 2001.

[7] T. Ondrejcak, I. Klyubin, N.-W. Hu, A. E. Barry, W. K. Cullen, and M. J. Rowan, "Alzheimer's disease amyloid $\beta$-protein and synaptic function," NeuroMolecular Medicine, vol. 12, no. 1, pp. 13-26, 2010.

[8] F. Peña-Ortega, "Amyloid $\beta$-protein and neural network dysfunction," Journal of Neurodegenerative Diseases, vol. 2013, Article ID 657470, 8 pages, 2013.

[9] A. Adaya-Villanueva, B. Ordaz, H. Balleza-Tapia, A. MárquezRamos, and F. Peña-Ortega, " $\beta$-like hippocampal network activity is differentially affected by amyloid $\beta$ peptides," Peptides, vol. 31, no. 9, pp. 1761-1766, 2010.

[10] T. Iwatsubo, A. Odaka, N. Suzuki, H. Mizusawa, N. Nukina, and Y. Ihara, "Visualization of $A \beta 42(43)$ and $A \beta 40$ in senile plaques with end-specific $\mathrm{A} \beta$ monoclonals: evidence that an initially deposited species is A $\beta 42$ (43)," Neuron, vol. 13, no. 1, pp. 45-53, 1994.

[11] A. Güntert, H. Döbeli, and B. Bohrmann, "High sensitivity analysis of amyloid- $\beta$ peptide composition in amyloid deposits from human and PS2APP mouse brain," Neuroscience, vol. 143, no. 2, pp. 461-475, 2006.

[12] C. J. Pike, A. J. Walencewicz-Wasserman, J. Kosmoski, D. H. Cribbs, C. G. Glabe, and C. W. Cotman, "Structure-activity analyses of $\beta$-amyloid peptides: contributions of the $\beta 25-35$ region to aggregation and neurotoxicity," Journal of Neurochemistry, vol. 64, no. 1, pp. 253-265, 1995.

[13] T. Kubo, S. Nishimura, Y. Kumagae, and I. Kaneko, "In vivo conversion of racemized $\beta$ amyloid $\left(\left[\mathrm{D}-\mathrm{Ser}^{26}\right] \mathrm{A} \beta_{1-40}\right)$ to truncated and toxic fragments $\left(\left[\mathrm{D}-\mathrm{Ser}^{26}\right] \mathrm{A} \beta 25-35 / 40\right)$ and fragment presence in the brains of Alzheimer's patients," Journal of Neuroscience Research, vol. 70, no. 3, pp. 474-483, 2002.

[14] M. A. Gruden, T. B. Davudova, M. Mališauskas et al., "Autoimmune responses to amyloid structures of $\mathrm{A} \beta_{25-35}$ peptide and human lysozyme in the serum of patients with progressive Alzheimer's disease," Dementia and Geriatric Cognitive Disorders, vol. 18, no. 2, pp. 165-171, 2004.

[15] I. Kaneko, K. Morimoto, and T. Kubo, "Drastic neuronal loss in vivo by $\beta$-amyloid racemized at Ser26 residue: conversion of non-toxic [D-Ser26] $\beta$-amyloid 1-40 to toxic and proteinaseresistant fragments," Neuroscience, vol. 104, no. 4, pp. 1003-1011, 2001. 
[16] B. A. Yankner, L. K. Duffy, and D. A. Kirschner, "Neurotrophic and neurotoxic effects of amyloid $\beta$ protein: reversal by tachykinin neuropeptides," Science, vol. 250, no. 4978, pp. 279282, 1990

[17] M. P. Mattson, B. Cheng, D. Davis, K. Bryant, I. Lieberburg, and R. E. Rydel, " $\beta$-Amyloid peptides destabilize calcium homeostasis and render human cortical neurons vulnerable to excitotoxicity," Journal of Neuroscience, vol. 12, no. 2, pp. 376389, 1992.

[18] M.-K. Sun and D. L. Alkon, "Impairment of hippocampal CA1 heterosynaptic transformation and spatial memory by $\beta$ amyloid25-35," Journal of Neurophysiology, vol. 87, no. 5, pp. 2441-2449, 2002.

[19] F. Peña, B. Ordaz, H. Balleza-Tapia et al., " $\beta$-amyloid protein (25-35) disrupts hippocampal network activity: role of Fynkinase," Hippocampus, vol. 20, no. 1, pp. 78-96, 2010.

[20] S. Delobette, A. Privat, and T. Maurice, "In vitro aggregation facilitates $\beta$-amyloid peptide-(25-35)-induced amnesia in the rat," European Journal of Pharmacology, vol. 319, no. 1, pp. 1-4, 1997.

[21] D. B. Freir and C. E. Herron, "Nicotine enhances the depressive actions of $\mathrm{A} \beta 1-40$ on long-term potentiation in the rat hippocampal CA1 region in vivo," Journal of Neurophysiology, vol. 89, no. 6, pp. 2917-2922, 2003.

[22] D. B. Freir, D. A. Costello, and C. E. Herron, "A $\beta_{25-35}$-induced depression of long-term potentiation in area CA1 in vivo and in vitro is attenuated by verapamil," Journal of Neurophysiology, vol. 89, no. 6, pp. 3061-3069, 2003.

[23] E. A. Grace, C. A. Rabiner, and J. Busciglio, "Characterization of neuronal dystrophy induced by fibrillar amyloid $\beta$ : implications for Alzheimer's disease," Neuroscience, vol. 114, no. 1, pp. 265273,2002

[24] C. Holscher, S. Gengler, V. A. Gault, P. Harriott, and H. A. Mallot, "Soluble $\beta$-amyloid[25-35] reversibly impairs hippocampal synaptic plasticity and spatial learning," European Journal of Pharmacology, vol. 561, no. 1-3, pp. 85-90, 2007.

[25] T. Maurice, B. P. Lockhart, and A. Privat, "Amnesia induced in mice by centrally administered $\beta$-amyloid peptides involves cholinergic dysfunction," Brain Research, vol. 706, no. 2, pp. 181193, 1996.

[26] M. Y. Stepanichev, I. M. Zdobnova, I. I. Zarubenko et al., "A $\beta_{25-35}$-induced memory impairments correlate with cell loss in rat hippocampus," Physiology and Behavior, vol. 80, no. 5, pp. 647-655, 2004.

[27] C. Tohda, N. Matsumoto, K. Zou, M. R. Meselhy, and K. Komatsu, " $\mathrm{A} \beta_{25-35}$-induced memory impairment, axonal atrophy, and synaptic loss are ameliorated by MI, A metabolite of protopanaxadiol-type saponins," Neuropsychopharmacology, vol. 29, no. 5, pp. 860-868, 2004.

[28] Y. Yamaguchi and S. Kawashima, "Effects of amyloid- $\beta-(25-$ 35) on passive avoidance, radial-arm maze learning and choline acetyltransferase activity in the rat," European Journal of Pharmacology, vol. 412, no. 3, pp. 265-272, 2001.

[29] R. Rönicke, A. Klemm, J. Meinhardt, U. H. Schröder, M. Fändrich, and K. G. Reymann, "AB mediated diminution of MTT reduction-an artefact of single cell culture?" PLoS ONE, vol. 3, no. 9, Article ID e3236, 2008.

[30] H. Hiruma, T. Katakura, S. Takahashi, T. Ichikawa, and T. Kawakami, "Glutamate and amyloid $\beta$-protein rapidly inhibit fast axonal transport in cultured rat hippocampal neurons by different mechanisms," Journal of Neuroscience, vol. 23, no. 26, pp. 8967-8977, 2003.
[31] A. R. Korotzer, E. R. Whittenmore, and C. W. Cotman, "Differential regulation by $\beta$-amyloid peptides of intracellular free $\mathrm{Ca}^{2+}$ concentration in cultured rat microglia," European Journal of Pharmacology, vol. 288, no. 2, pp. 125-130, 1995.

[32] J. E. Driver, C. Racca, M. O. Cunningham et al., "Impairment of hippocampal gamma $(\gamma)$-frequency oscillations in vitro in mice overexpressing human amyloid precursor protein (APP)," European Journal of Neuroscience, vol. 26, no. 5, pp. 1280-1288, 2007.

[33] V. Villette, F. Poindessous-Jazat, A. Simon et al., "Decreased rhythmic GABAergic septal activity and memory-associated $\theta$ oscillations after hippocampal amyloid- $\beta$ pathology in the rat," Journal of Neuroscience, vol. 30, no. 33, pp. 10991-11003, 2010.

[34] F. Peña-Ortega and R. Bernal-Pedraza, "Amyloid $\beta$ peptide slows down sensory-induced hippocampal oscillations," International Journal of Peptides, vol. 2012, Article ID 236289, 8 pages, 2012.

[35] B. H. Bland and L. V. Colom, "Extrinsic and intrinsic properties underlying oscillation and synchrony in limbic cortex," Progress in Neurobiology, vol. 41, no. 2, pp. 157-208, 1993.

[36] M. J. Kahana, D. Seelig, and J. R. Madsen, “Theta returns," Current Opinion in Neurobiology, vol. 11, no. 6, pp. 739-744, 2001.

[37] M. J. Kahana, "The cognitive correlates of human brain oscillations," Journal of Neuroscience, vol. 26, no. 6, pp. 1669-1672, 2006.

[38] W. Klimesch, "EEG alpha and theta oscillations reflect cognitive and memory performance: a review and analysis," Brain Research Reviews, vol. 29, no. 2-3, pp. 169-195, 1999.

[39] A. L. Griffin, Y. Asaka, R. D. Darling, and S. D. Berry, "Theta-contingent trial presentation accelerates learning rate and enhances hippocampal plasticity during trace eyeblink conditioning," Behavioral Neuroscience, vol. 118, no. 2, pp. 403411, 2004

[40] N. McNaughton, M. Ruan, and M.-A. Woodnorth, "Restoring theta-like rythmicity in rats restores initial learning in the Morris water maze," Hippocampus, vol. 16, no. 12, pp. 1102-1110, 2006.

[41] T. Nakashiba, D. L. Buhl, T. J. McHugh, and S. Tonegawa, "Hippocampal CA3 output is crucial for ripple-associated reactivation and consolidation of memory," Neuron, vol. 62, no. 6, pp. 781-787, 2009.

[42] M. J. Kahana, R. Sekuler, J. B. Caplan, M. Kirschen, and J. R. Madsen, "Human theta oscillations exhibit task dependence during virtual maze navigation," Nature, vol. 399, no. 6738, pp. 781-784, 1999.

[43] B. R. Cornwell, L. L. Johnson, T. Holroyd, F. W. Carver, and C. Grillon, "Human hippocampal and parahippocampal theta during goal-directed spatial navigation predicts performance on a virtual Morris water maze," Journal of Neuroscience, vol. 28, no. 23, pp. 5983-5990, 2008.

[44] C. Babiloni, E. Cassetta, G. Binetti et al., "Resting EEG sources correlate with attentional span in mild cognitive impairment and Alzheimer's disease," European Journal of Neuroscience, vol. 25, no. 12, pp. 3742-3757, 2007.

[45] T. D. R. Cummins, M. Broughton, and S. Finnigan, "Theta oscillations are affected by amnestic mild cognitive impairment and cognitive load," International Journal of Psychophysiology, vol. 70, no. 1, pp. 75-81, 2008.

[46] J. Wang, S. Ikonen, K. Gurevicius, T. Van Groen, and H. Tanila, "Alteration of cortical EEG in mice carrying mutated human 
APP transgene," Brain Research, vol. 943, no. 2, pp. 181-190, 2002.

[47] J. P. Wisor, D. M. Edgar, J. Yesavage et al., "Sleep and circadian abnormalities in a transgenic mouse model of Alzheimer's disease: a role for cholinergic transmission," Neuroscience, vol. 131, no. 2, pp. 375-385, 2005.

[48] M. Akay, K. Wang, Y. M. Akay, A. Dragomir, and J. Wu, "Nonlinear dynamical analysis of carbachol induced hippocampal oscillations in mice," Acta Pharmacologica Sinica, vol. 30, no. 6, pp. 859-867, 2009.

[49] B. Platt, B. Drever, D. Koss et al., "Abnormal cognition, sleep, eeg and brain metabolism in a novel knock-in alzheimer mouse, plb1," PLoS ONE, vol. 6, no. 11, Article ID e27068, 2011.

[50] L. Scott, J. Feng, T. Kiss, E. Needle, K. Atchison, and T. T. Kawabe, "Age-dependent disruption in hippocampal theta oscillation in amyloid- $\beta$ overproducing transgenic mice," $\mathrm{Neu}$ robiol Aging, vol. 33, pp. e13-e23, 2012.

[51] L. V. Colom, "Septal networks: relevance to theta rhythm, epilepsy and Alzheimer's disease," Journal of Neurochemistry, vol. 96, no. 3, pp. 609-623, 2006.

[52] J. Shin, "Theta rhythm heterogeneity in humans," Clinical Neurophysiology, vol. 121, no. 3, pp. 456-457, 2010.

[53] J. Pálhalmi, O. Paulsen, T. F. Freund, and N. Hájos, "Distinct properties of carbachol- and DHPG-induced network oscillations in hippocampal slices," Neuropharmacology, vol. 47, no. 3 , pp. 381-389, 2004.

[54] C. G. Reich, M. A. Karson, S. V. Karnup, L. M. Jones, and B. E. Alger, "Regulation of IPSP theta rhythm by muscarinic receptors and endocannabinoids in hippocampus," Journal of Neurophysiology, vol. 94, no. 6, pp. 4290-4299, 2005.

[55] K. M. Cullen, G. M. Halliday, K. L. Double, W. S. Brooks, H. Creasey, and G. A. Broe, "Cell loss in the nucleus basalis is related to regional cortical atrophy in Alzheimer's disease," Neuroscience, vol. 78, no. 3, pp. 641-652, 1997.

[56] D. S. Auld, T. J. Kornecook, S. Bastianetto, and R. Quirion, "Alzheimer's disease and the basal forebrain cholinergic system: relations to $\beta$-amyloid peptides, cognition, and treatment strategies," Progress in Neurobiology, vol. 68, no. 3, pp. 209-245, 2002.

[57] M. Klingner, J. Apelt, A. Kumar et al., "Alterations in cholinergic and non-cholinergic neurotransmitter receptor densities in transgenic Tg2576 mouse brain with $\beta$-amyloid plaque pathology," International Journal of Developmental Neuroscience, vol. 21, no. 7, pp. 357-369, 2003.

[58] H.-J. Lüth, J. Apelt, A. O. Ihunwo, T. Arendt, and R. Schliebs, "Degeneration of $\beta$-amyloid-associated cholinergic structures in transgenic APPSW mice," Brain Research, vol. 977, no. 1, pp. 16-22, 2003.

[59] Y. Ikarashi, Y. Harigaya, Y. Tomidokoro et al., "Decreased level of brain acetylcholine and memory disturbance in APPsw mice," Neurobiology of Aging, vol. 25, no. 4, pp. 483-490, 2004.

[60] X. Ma, W. Ye, and Z. Mei, "Change of cholinergic transmission and memory deficiency induced by injection of $\beta$-amyloid protein into NBM of rats," Science in China Series C, vol. 44, no. 4, pp. 435-442, 2001.

[61] L. Fang, J. Duan, D. Ran, Z. Fan, Y. Yan, and N. Huang, "Amyloid- $\beta$ depresses excitatory cholinergic synaptic transmission in Drosophila," Neuroscience Bulletin, vol. 28, pp. 585-594, 2012.

[62] H. Balleza-Tapia, A. Huanosta-Gutiérrez, A. Márquez-Ramos, N. Arias, and F. Peña, "Amyloid $\beta$ oligomers decrease hippocampal spontaneous network activity in an age-dependent manner," Current Alzheimer Research, vol. 7, no. 5, pp. 453-462, 2010.

[63] R. N. Leão, L. V. Colom, L. Borgius, O. Kiehn, and A. Fisahn, "Medial septal dysfunction by $\mathrm{A} \beta$-induced KCNQ channelblock in glutamatergic neurons," Neurobiology of Aging, vol. 33, pp. 2046-2061, 2012.

[64] L. V. Colom, M. T. Castañeda, C. Bañuelos et al., "Medial septal $\beta$-amyloid 1-40 injections alter septo-hippocampal anatomy and function," Neurobiology of Aging, vol. 31, no. 1, pp. 46-57, 2010.

[65] E. A. Mugantseva and I. Y. Podolski, "Animal model of Alzheimer's disease: characteristics of EEG and memory," Central European Journal of Biology, vol. 4, no. 4, pp. 507-514, 2009.

[66] Y.-M. Kuo, M. R. Emmerling, C. Vigo-Pelfrey et al., "Watersoluble $\mathrm{A}^{\beta}(\mathrm{N}-40, \mathrm{~N}-42)$ oligomers in normal and Alzheimer disease brains," Journal of Biological Chemistry, vol. 271, no. 8, pp. 4077-4081, 1996.

[67] W. E. Klunk, B. J. Lopresti, M. D. Ikonomovic et al., "Binding of the positron emission tomography tracer Pittsburgh Compound-B reflects the amount of amyloid- $\beta$ in Alzheimer's Disease brain but not in transgenic mouse brain," Journal of Neuroscience, vol. 25, no. 46, pp. 10598-10606, 2005.

[68] T. Matsui, M. Ingelsson, H. Fukumoto et al., "Expression of APP pathway mRNAs and proteins in Alzheimer's disease," Brain Research, vol. 1161, no. 1, pp. 116-123, 2007.

[69] M. D. Ikonomovic, W. E. Klunk, E. E. Abrahamson et al., "Postmortem correlates of in vivo PiB-PET amyloid imaging in a typical case of Alzheimer's disease," Brain, vol. 131, no. 6, pp. 1630-1645, 2008.

[70] J. R. Steinerman, M. Irizarry, N. Scarmeas et al., "Distinct pools of $\beta$-amyloid in Alzheimer disease-affected brain: a clinicopathologic study," Archives of Neurology, vol. 65, no. 7, pp. 906-912, 2008.

[71] I. Dewachter, J. Van Dorpe, L. Smeijers et al., "Aging increased amyloid peptide and caused amyloid plaques in brain of old APP/V717I transgenic mice by a different mechanism than mutant presenilin1," Journal of Neuroscience, vol. 20, no. 17, pp. 6452-6458, 2000.

[72] D. Praticó, K. Uryu, S. Sung, S. Tang, J. Q. Trojanowski, and V. M.-Y. Lee, "Aluminum modulates brain amyloidosis through oxidative stress in APP transgenic mice," The FASEB Journal, vol. 16, no. 9, pp. 1138-1140, 2002.

[73] J.-Y. Lee, J. E. Friedman, I. Angel, A. Kozak, and J.-Y. Koh, “The lipophilic metal chelator DP-109 reduces amyloid pathology in brains of human $\beta$-amyloid precursor protein transgenic mice," Neurobiology of Aging, vol. 25, no. 10, pp. 1315-1321, 2004.

[74] J. L. Jankowsky, L. H. Younkin, V. Gonzales et al., "Rodent A $\beta$ modulates the solubility and distribution of amyloid deposits in transgenic mice," Journal of Biological Chemistry, vol. 282, no. 31, pp. 22707-22720, 2007.

[75] Y. Shinkai, M. Yoshimura, M. Morishima-Kawashima et al., "Amyloid $\beta$-protein deposition in the leptomeninges and cerebral cortex," Annals of Neurology, vol. 42, no. 6, pp. 899-908, 1997.

[76] J. Wang, D. W. Dickson, J. Q. Trojanowski, and V. M.-Y. Lee, "The levels of soluble versus insoluble brain a $\beta$ distinguish Alzheimer's disease from normal and pathologic aging," Experimental Neurology, vol. 158, no. 2, pp. 328-337, 1999.

[77] J. Fonte, J. Miklossy, C. Atwood, and R. Martins, "The severity of cortical Alzheimer's type changes is positively correlated with increased amyloid- $\beta$ levels: resolubilization of amyloid- $\beta$ with 
transition metal ion chelators," Journal of Alzheimer's Disease, vol. 3, no. 2, pp. 209-219, 2001.

[78] R. L. Patton, W. M. Kalback, C. L. Esh et al., "Amyloid- $\beta$ peptide remnants in AN-1792-immunized Alzheimer's disease patients: a biochemical analysis," American Journal of Pathology, vol. 169, no. 3, pp. 1048-1063, 2006.

[79] K. A. Bates, G. Verdile, Q.-X. Li et al., "Clearance mechanisms of Alzheimer's amyloid-B peptide: implications for therapeutic design and diagnostic tests," Molecular Psychiatry, vol. 14, no. 5, pp. 469-486, 2009.

[80] G. C. Gregory and G. M. Halliday, "What is the dominant a $\beta$ species in human brain tissue? A review," Neurotoxicity Research, vol. 7, no. 1-2, pp. 29-41, 2005.

[81] F. Peña and N. Alavez-Pérez, "Epileptiform activity induced by pharmacologic reduction of M-current in the developing hippocampus in vitro," Epilepsia, vol. 47, no. 1, pp. 47-54, 2006.

[82] J. M. Fellous and T. J. Sejnowski, "Cholinergic induction of oscillations in the hippocampal slice in the slow $(0.5-2 \mathrm{~Hz})$, theta $(5-12 \mathrm{~Hz})$, and gamma $(35-70 \mathrm{~Hz})$ bands," Hippocampus, vol. 10, pp. 187-197, 2000.

[83] K. Wíniewski and H. Car, “(S)-3,5-DHPG: a review," CNS Drug Reviews, vol. 8, no. 1, pp. 101-116, 2002.

[84] G. Buzsáki, "Theta oscillations in the hippocampus," Neuron, vol. 33, no. 3, pp. 325-340, 2002.

[85] J. Shin, D. Kim, R. Bianchi, R. K. S. Wong, and H.-S. Shin, "Genetic dissection of theta rhythm heterogeneity in mice," Proceedings of the National Academy of Sciences of the United States of America, vol. 102, no. 50, pp. 18165-18170, 2005.

[86] F. Nobili, F. Copello, P. Vitali et al., "Timing of disease progression by quantitative EEG in Alzheimer's patients," Journal of Clinical Neurophysiology, vol. 16, no. 6, pp. 566-573, 1999.

[87] A. Jyoti, A. Plano, G. Riedel, and B. Platt, "EEG, activity, and sleep architecture in a transgenic A $\beta$ PPswe/PSEN1A246E Alzheimer's disease mouse," Journal of Alzheimer's Disease, vol. 22, pp. 873-887, 2010.

[88] F. M. LaFerla, K. N. Green, and S. Oddo, "Intracellular amyloid$\beta$ in Alzheimer's disease," Nature Reviews Neuroscience, vol. 8, no. 7, pp. 499-509, 2007.

[89] L. Verret, E. O. Mann, G. B. Hang et al., "Inhibitory interneuron deficit links altered network activity and cognitive dysfunction in alzheimer model," Cell, vol. 149, no. 3, pp. 708-721, 2012.

[90] G. J. Chen, Z. Xiong, and Z. Yan, "A $\beta$ impairs nicotinic regulation of inhibitory synaptic transmission and interneuron excitability in prefrontal cortex," Molecular Neurodegeneration, vol. 8, article 3, 2013.

[91] S. E. Rubio, G. Vega-Flores, A. Martinez, C. Bosch, A. PerezMediavilla, and J. del Rio, "Accelerated aging of the GABAergic septohippocampal pathway and decreased hippocampal rhythms in a mouse model of Alzheimer's disease," The FASEB Journal, vol. 26, pp. 4458-4467, 2012.

[92] C. A. Chapman and J.-C. Lacaille, "Cholinergic induction of theta-frequency oscillations in hippocampal inhibitory interneurons and pacing of pyramidal cell firing," Journal of Neuroscience, vol. 19, no. 19, pp. 8637-8645, 1999.

[93] C. C. Felder, "Muscarinic acetylcholine receptors: signal transduction through multiple effectors," The FASEB Journal, vol. 9, no. 8, pp. 619-625, 1995.

[94] H.-M. Huang, H.-C. Ou, and S.-J. Hsieh, "Amyloid $\beta$ peptide impaired carbachol but not glutamate-mediated phosphoinositide pathways in cultured rat cortical neurons," Neurochemical Research, vol. 25, no. 2, pp. 303-312, 2000.
[95] H. Janickova, V. Rudajev, P. Zimcik, J. Jakubik, H. Tanila, and E. E. El-Fakahany, "Uncoupling of M1 muscarinic receptor/Gprotein interaction by amyloid $\beta_{1-42}$," Neuropharmacology, vol. 67, pp. 272-283, 2013.

[96] K. N. Dahlgren, A. M. Manelli, W. Blaine Stine Jr., L. K. Baker, G. A. Krafft, and M. J. Ladu, "Oligomeric and fibrillar species of amyloid- $\beta$ peptides differentially affect neuronal viability," Journal of Biological Chemistry, vol. 277, no. 35, pp. 3204632053, 2002.

[97] E. McGowan, F. Pickford, J. Kim et al., "A $\beta 42$ is essential for parenchymal and vascular amyloid deposition in mice," Neuron, vol. 47, no. 2, pp. 191-199, 2005.

[98] G. Bitan, M. D. Kirkitadze, A. Lomakin, S. S. Vollers, G. B. Benedek, and D. B. Teplow, "Amyloid $\beta$-protein $(\mathrm{A} \beta)$ assembly: $\mathrm{A} \beta 40$ and $\mathrm{A} \beta 42$ oligomerize through distinct pathways," Proceedings of the National Academy of Sciences of the United States of America, vol. 100, no. 1, pp. 330-335, 2003.

[99] A. Sandberg, L. M. Luheshi, S. Söllvander et al., "Stabilization of neurotoxic Alzheimer amyloid- $\beta$ oligomers by protein engineering," Proceedings of the National Academy of Sciences of the United States of America, vol. 107, no. 35, pp. 15595-15600, 2010.

[100] H. Lin, R. Bhatia, and R. Lal, "Amyloid $\beta$ protein forms ion channels: implications for Alzheimer's disease pathophysiology," The FASEB Journal, vol. 15, no. 13, pp. 2433-2444, 2001. 

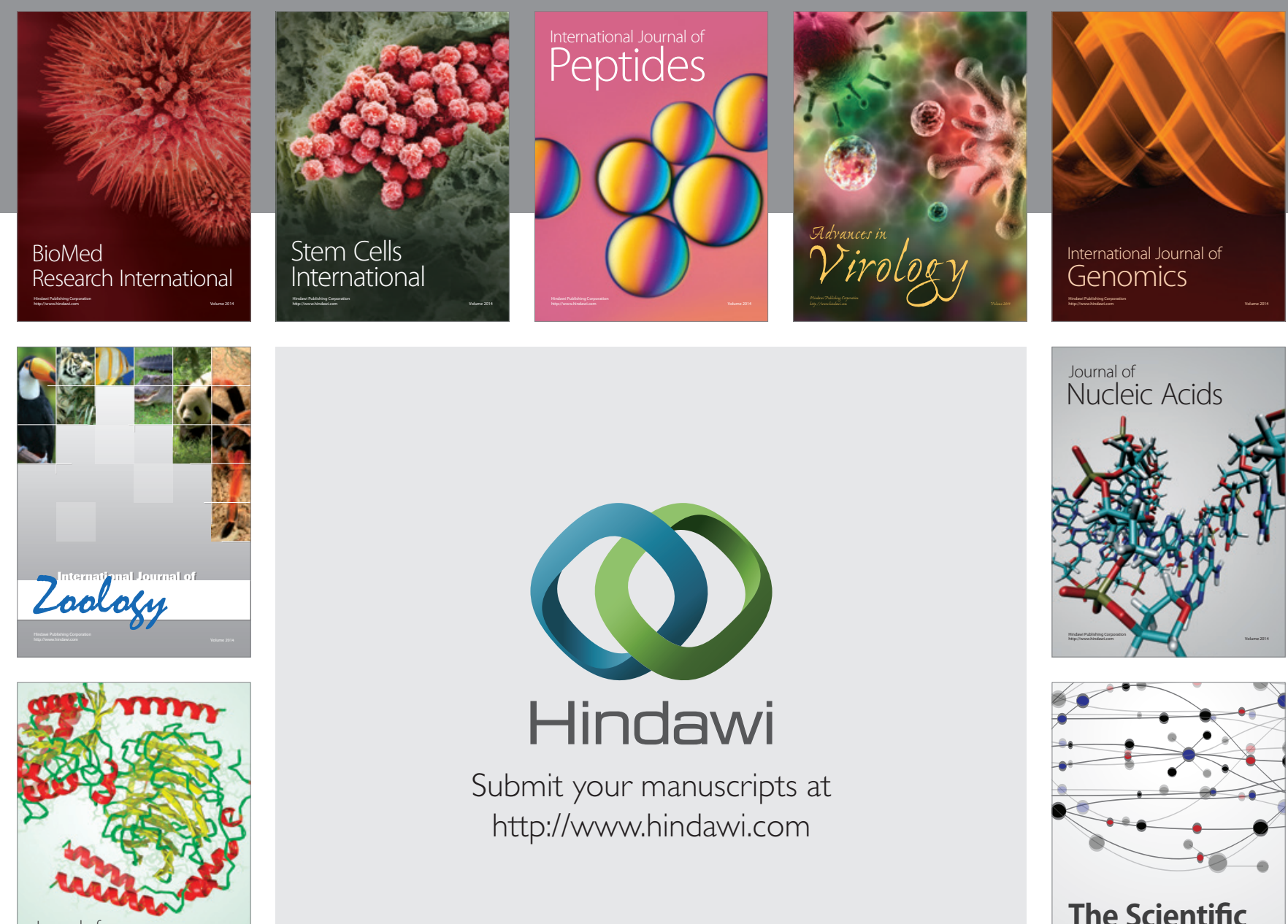

Submit your manuscripts at

http://www.hindawi.com

Journal of
Signal Transduction
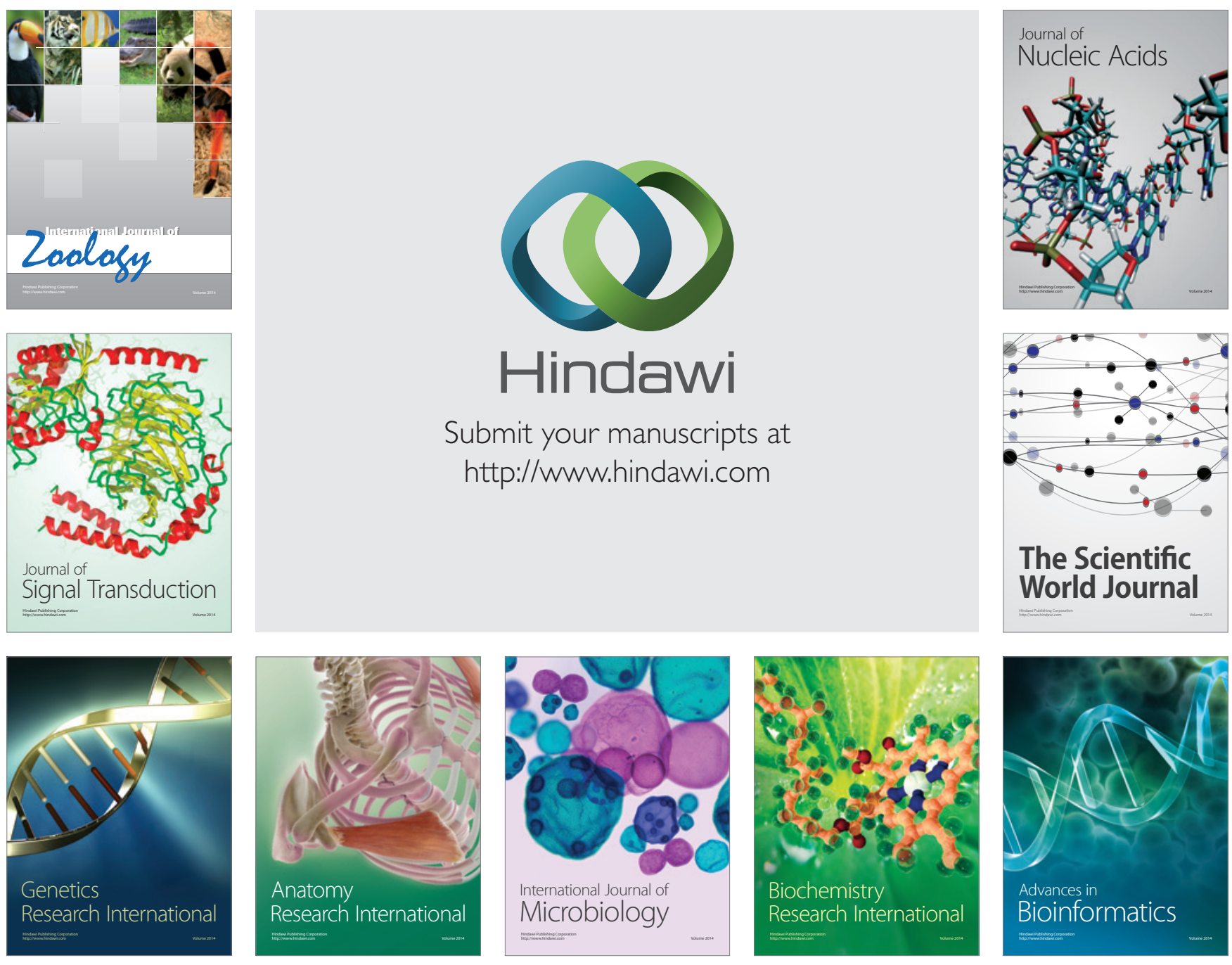

The Scientific World Journal
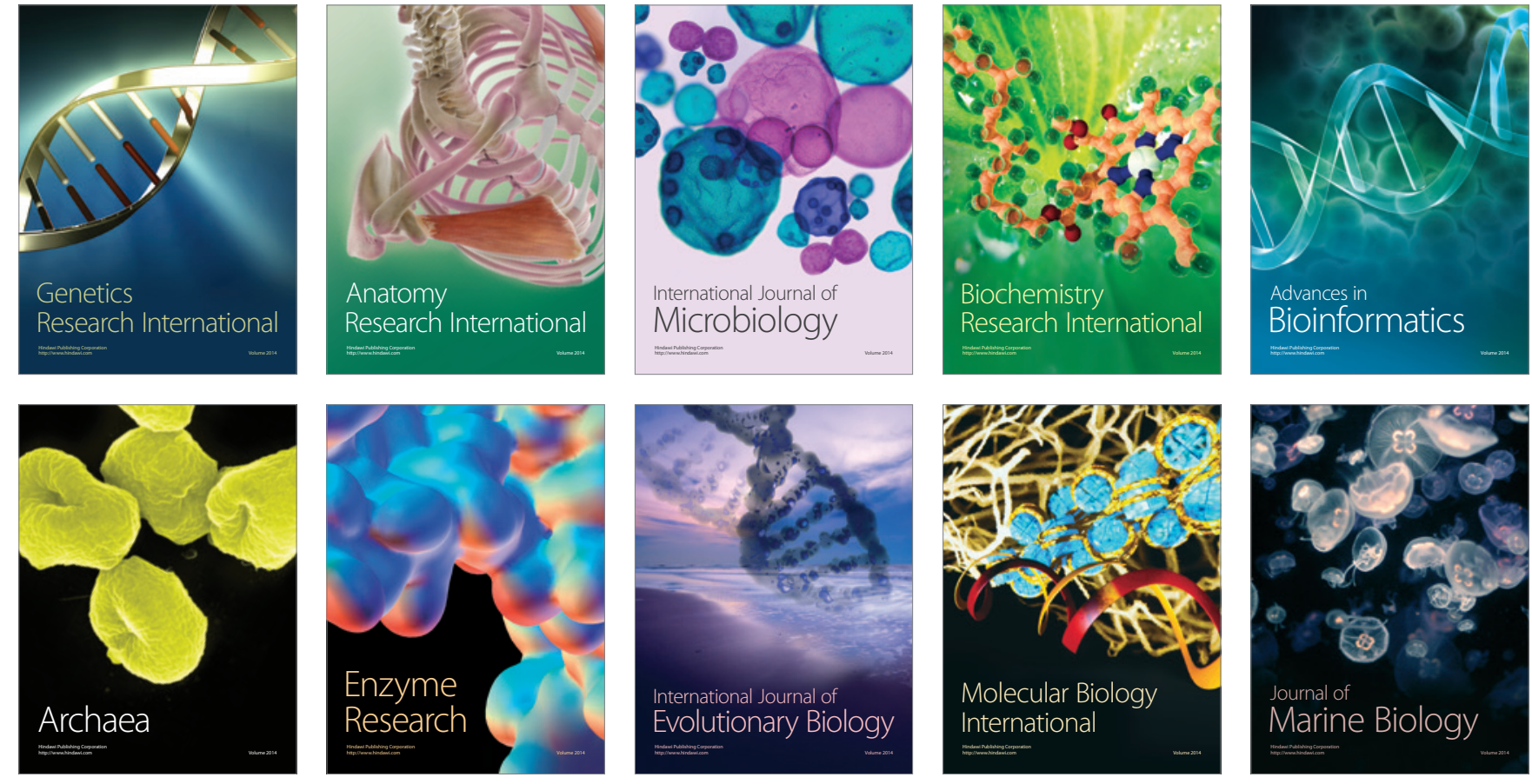